\title{
I TATTI STUDIES IN
}

ITALIAN RENAISSANCE HISTORY

\section{标}

Published in collaboration with I Tatti

The Harvard University Center for Italian Renaissance Studies Florence, Italy 
GENERAL EDITOR

Kate Lowe 


\section{TUSCANY IN THE AGE OF EMPIRE}

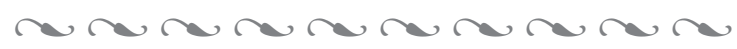

\section{B R I A N B R G E}

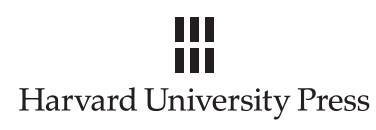

Cambridge, Massachusetts

London, England

2021 
Copyright ( $\odot 2021$ by the President and Fellows of Harvard College All rights reserved

Printed in the United States of America

First printing

Jacket image: Map of Italy (detail), 1578, by Stefano Bonsignori/ Wikimedia Jacket Design: Tim Jones

$$
\begin{aligned}
& \text { ISBN } 9780674258778 \text { (Epub) } \\
& \text { ISBN } 9780674258761 \text { (PDF) }
\end{aligned}
$$

Library of Congress Cataloging-in-Publication Data

Names: Brege, Brian, 1985- author.

Title: Tuscany in the age of empire / Brian Brege.

Other titles: I Tatti studies in Italian Renaissance history.

Description: Cambridge, Massachusetts : Harvard University Press, 2021.

Series: I Tatti studies in Italian Renaissance history | Includes

bibliographical references and index.

Identifiers: LCCN 2020044805 |

Subjects: LCSH: Tuscany (Italy)-Politics and government-1434-1737. |

Tuscany (Italy)-Economic conditions-1434-1737. | Tuscany

(Italy)-Foreign relations.

Classification: LCC DG737.3 .B74 2021 | DDC 945/.506-dc23

LC record available at https://lccn.loc.gov/2020044805 
For M.A.C. 
